\title{
Morphological Awareness of 1st to 3rd Grade School- Aged Children from Multicultural Families
}

\author{
Eun Ha Kim, Kyung Hee Jung \\ Department of Speech Language Rehabilitation, Yongin University, Yongin, Korea
}

\author{
Correspondence: Kyung Hee Jung, PhD \\ Department of Speech Language Rehabilitation, \\ Yongin University, 134 Yongindaehak-ro, \\ Cheoin-gu, Yongin 449-714, Korea \\ Tel: $+82-31-8020-2864$ \\ Fax: +82-31-8020-3075 \\ E-mail: 1012jkh@hanmail.net
}

Received: April 2, 2015

Revised: May 12, 2015

Accepted: May 14, 2015

This work is based on a part of the first author's master's thesis from Yongin University.

\begin{abstract}
Objectives: The purpose of this study was to investigate the morphological awareness of 1 st to 3 rd grade students from multicultural families and non-multicultural families. Methods: The subjects of this study were 13 students from multicultural families and 13 students from non-multicultural families. The experiments consisted of morphological awareness, decoding, reading fluency, and reading comprehension ability tasks. Frequency of correct answers and frequency of incorrect answers were compared and analyzed for the respective groups. Results: The results of this study can be summarized as follows. First, there were significant differences in morphological awareness between the two groups, with students from multicultural families performing worse. Additionally, there were significant differences in the opaque type, derivation type, and combination type of morphological awareness tests, again with children from multicultural families performing below their peers. Second, there were significant differences in double use error types and nontransformation error types. The children from multicultural families showed errors more frequently than those from non-multicultural families. Third, there were significant correlations between morphological awareness and all other reading variables in the two groups. Conclusion: The results of the present study suggest that in spite of normal receptive vocabulary development and reading ability, children from multicultural families display lower mean values in morphological awareness than their peers from non-multicultural families.
\end{abstract}

Keywords: Multicultural family, Morphological awareness, School-aged children, Transparency, Derivation

\begin{abstract}
최근 우리나라는 외국인 노동자의 유입과 국제결혼에 의한 결혼 이주 여성의 증가로 다문화가정의 수가 늘어났으며, 그에 따른 다문 화가정 아동에 대한 연구도 활발히 이루어져 왔다. 행정안전부 자 료에 따르면 다문화가정 아동의 수는 2014년 1월 20만 명을 초과하 였으며, 미취학 아동 및 초등학생이 약 $83.9 \%$ 에 이른다(Korea Ministry of Government Administration and Home Affairs, 2014). 지 금까지의 많은 연구에서 다문화가정 아동들은 비다문화가정 아동 들에 비해 언어 전반적인 영역에서 어려움을 경험하는 것으로 밝혀 졌다(Hwang \& Jeong, 2008; Kim, 2011; Kim, 2009).

더욱이 학령기로 접어들게 되면 학업 및 학교 적응과 관련된 언 어 및 읽기 능력의 중요성이 커지게 된다. 특히, 학습을 위한 언어 및 읽기.쓰기 능력은 무엇보다 학교 적응을 위해 중요하게 갖추어야
\end{abstract}

할 능력으로 강조되어 오고 있다. 다문화가정 아동들도 학령기에 접어들게 되면 이와 관련된 또 다른 어려움에 직면하게 된다. 최근 여러 연구들을 통해 음운인식, 낱말재인, 읽기유창성, 읽기 이해 등 을 중심으로 한 읽기 능력에서 다문화가정 아동들의 수행력이 낮 다는 보고가 이루어져 왔다(Kwon \& Seok, 2009; Pae \& Kim, 2010; Shim \& Jung, 2012).

초등학교 아동의 초기 교육과정은 주로 읽기를 통한 정보 습득 과 학습으로 이루어진다. 학령기 아동에게 있어서 읽기는 중요한 발달 영역이며, 교과이해를 위한 중요한 능력이다. 인쇄된 글자로 이루어진 텍스트를 읽기 위해서는 무엇보다 쓰여진 단어를 읽을 수 있는 해독 능력과 텍스트의 내용을 이해하기 위한 읽기 이해 능력 이 숙달되어야 한다. 낱말읽기는 자소와 음소의 대응규칙을 적용 
하여 글자를 해독하고, 익숙한 낱말을 일견 단어로 읽어내는 능력 을 발달시킴으로써 숙달될 수 있다. 낱말 해독 능력이 숙달되어 자 동적으로 읽기가 가능해지면 읽은 내용을 이해하는 데 더 집중할 수 있게 됨으로써 궁극적으로 이해하기 위해 읽는 단계로 나아갈 수 있게 된다. 이때 읽은 내용을 이해하기 위해서는 텍스트 내의 어 휘를 비롯한 언어적 내용과 형식에 대한 이해능력이 기반이 되어야 한다. 읽기의 이러한 특성 때문에 언어장애 아동들이 학령기가 되 면 읽기의 어려움에 직면하게 되는 경우가 많다.

읽기능력의 발달은 또한 메타언어능력과 관련이 있는 것으로 밝 혀져 왔다(Ahn, Heo, \& Seo, 2012; Cho, 2003; Jarmulowicz, Taran, \& Hay, 2007; Kim, 2014). 특히, 학령기 아동에게 있어서 아동의 학 습 및 읽기능력과 관련이 높고, 학령기 아동의 메타언어능력 부족 은 아동의 읽기와 교과 과정 학습에 어려움으로 이어질 수 있다 (Kim, 2014). 이러한 메타언어 능력에 대하여 국내 외의 많은 연구 에서 음운인식에 관한 연구가 활발하게 이루어져 왔다. 낱말의 음 운구조를 인식하고 조작할 수 있는 음운인식능력은 낱말 해독하 는데 있어 구어와 문어를 연결하는 역할을 한다(Gillon, 2004). 음 운인식능력이 낱말재인뿐 아니라 읽기 능력 전반을 예측해주는 설 명력이 높은 요인이라는 점은 많은 연구를 통해서 밝혀져 왔다(Kim, 2014; Nation \& Snowling, 2004). Kwon과 Seok (2010)은 다문화가 정 아동의 경우 일반가정 아동에 비해 생략, 합성, 변별 검사로 이루 어진 음운인식과제의 수행력이 낮은 것으로 나타났으며, 학년이 올 라갈수록 이러한 수행점수의 차이가 근소해진다고 하였다. 메타구 문능력을 평가한 Kim과 Kim (2011)은 지능과 언어 및 학습능력에 차이가 없음에도 불구하고, 다문화가정 아동의 문법성 판단과 오 류수정 능력이 낮게 나타났다고 보고하였다. 이러한 연구결과는 다문화가정 아동이 메타음운 및 메타구문론적인 측면에서의 상위 언어능력면에서 일반가정 아동에 비해 어려움을 겪을 가능성이 있 으며 평가와중재 시 이를 고려해야함을 시사해 주고 있다.

한편 최근 외국 연구를 보면 읽기 발달에 영향을 미치는 요인으 로서 메타언어 능력과 관련된 변인의 하나인 형태소인식능력에 대 한 중요성이 논의되고 있다(Daecon \& Kirby, 2004; Jarmulowicz et al., 2007; Nagy \& Anderson, 1995). 형태소란 의미를 가진 최소 단 위로 구어와 문어에서 단어의 기초를 이루며, 단어는 하나 이상의 형태소의 결합으로 이루어져 있다. 형태소의 결합으로 이루어진 단 어는 굴절어, 합성어, 파생어를 이룬다. 굴절어는 단어범주의 변화 없이 문장 내 문법적 기능을 바꾸는 조사나 어미를 포함하고 있다. 조사나 어미로 구성된 굴절어 사용능력은 구문의 이해 및 표현 등 을 포함한 구어능력과 관련하여 많은 연구자의 관심을 받아왔다 (Hwang, 2003; Jung \& Pae, 2010). 한편, 하나 이상의 형태소가 모여
단어를 이루는데 단일어는 하나의 형태소가 하나의 단어를 이룬 것이고, 두 개 이상의 형태소가 모여 이루어진 단어를 복합어라고 한다. 복합어 중 어근과 어근의 결합으로 이루어진 단어를 합성어, 어근과 파생접사로 이루어진 단어를 파생어라고 한다. 합성어와 파 생어는 기본 형태소로부터 의미가 다르고 단어범주가 다를 수 있 는 새로운 단어를 생성하는 조어과정에 관련되어 있다. 형태소인식 능력은 의미를 가진 최소 단위인 형태소에 대해 의식적으로 생각하 고, 조작하고, 형태소의 결합으로 이루어진 단어 형성의 규칙을 적 용하는 능력이다(Jung, 2014). 형태소가 새로운 단어의 의미를 표현 하기 위해 조합될 수 있는 방식을 이해하는 것은 복합어로 이루어 진 새로운 단어에 접근하는 데 용이하다. 더욱이 한자어에서 비롯 된 접두사나 접미사가 포함된 복합어가 학령기 학업과 관련된 어휘 의 다수를 차지하고 있는 한국어에서 합성어와 파생어 조어와 관 련된 형태소의 사용능력은 학습능력에 많은 영향을 미칠 것으로 사료된다.

Kuo와 Anderson (2006)은 학년이 높아지면서 아이들은 더 많은 학습적인(academic) 단어들에 대하여 노출 되고, 이때의 단어들은 형태학적으로 복잡하며, 구어 언어에서의 사용이 적기 때문에 이 시기에 형태소인식능력의 요구가 증가한다고 하였다. Berninger, Abbott, Nagy와 Carlisle (2010)은 형태소인식능력은 성장곡선 분 석결과 1-3학년까지 가장 활발하게 발달하고 그 이후 발달이 6학년 까지 지속적으로 이루어진다고 하였다. Nagy와 Anderson (1995)은 형태소인식이 읽기능력의 다양한 방면에 영향을 미치며 그 영향은 문자체계를 알 수 있게 해주고, 더 정확하고 더 유창하게 복합어를 읽고 쓰는 것을 도와주며, 아동이 언어 환경에 의존하는 것을 줄여 주고, 구어와 문어 어휘의 학습과 문장분석과 읽기이해를 촉진시 킨다고 하였다. 국내에서도 형태소인식능력에 대한 관심이 시작되 고 있는데 Kim (2012)을 형태소의 처리는 복합어의 인지뿐만 아니 라 비단어 읽기, 쓰기 등에서 필수적이며, 음운인식 능력 못지 않게 독서 능력 발달에 중요한 변인으로 작용한다고 하였다. 최근 Jung (2014)은 정상 발달하는 초등 1-3학년의 형태소인식능력이 단어재 인 및 읽기 이해능력을 예측해주는 주요 변인임을 밝혔다. 즉, 형태 소인식능력은 학령기에 습득해야 할 학습관련 어휘지식뿐 아니라 읽기 능력과 중요한 관계가 있는 상위언어능력이라고 할 수 있다.

굴절형태소는 초기에 습득되나, 파생과 합성형태소의 발달은 학 령기 후기까지, 파생형태소의 경우 초등기 이후까지 지속적으로 발 달한다(Goodwin et al., 2012). 학령기에 새로운 의미의 단어 생성 에 관련된 합성 및 파생어 인식능력은 잘 모르는 단어의 해석을 지 원해줌으로써 한 번도 노출된 적이 없는 단어의 의미를 해석하는 데 기여하게 된다. 이는 텍스트 내 읽기처리 속도를 증가시켜 궁극 
적으로 텍스트 이해에 도움을 준다. 학령기 교과과정에서 다루는 텍스트의 상당수가 형태론적으로 복잡한 단어로 이루어진 점을 고려할 때, 조어 관련 형태소인식능력은 읽기능력 전반과 관련될 수 있다.

그런데 복합어를 이루는 과정에서 두 개의 형태소가 음운론적, 철자적으로 변함이 없는 단어도 있지만(예, 구슬-구슬비) 음운이 변하거나(예, 과학-과학자) 철자가 변하는 것(바늘-바느질)도 있다. 음운 철자 투명도는 형태소 구조를 인식하는 데 중요한 영향을 미 친다(Carlisle \& Stone, 2005). Carlisle $(1987,1988)$ 은 정상발달 아 동과 학습장애 아동 모두 음운론적으로 투명한 단어를 더 잘 인식 한다고 하였고, Shankweiler 등(1995)은 읽기우수 아동과 읽기부 진 아동들이 투명한 과제에서는 차이가 없으나 불투명한 과제에서 는 읽기부진 아동의 수행력이 낮다고 하였다. 최근 읽기부진 아동 과 일반 아동의 형태소인식능력을 비교한 Kim (2014)은 두 집단 아 동 모두 투명한 과제보다 불투명한 과제가, 합성보다 파생이, 분리과 제보다 결합과제에 대한 수행력이 유의하게 높았다고 보고하였다.

이처럼 형태소인식능력은 어휘 및 읽기 능력과 관련해서 최근 많 은 주목을 받아오고 있으나 국내에서는 문법형태소를 중심으로 굴 절어에 대한 연구가 주를 이루고 있다. 조어 관련 형태소 인식능력 에 대한 연구는 최근 몇몇 연구자들에 의해 이루어지고 있으나 일 반 아동이나 학습부진 아동에 관한 연구에 한정되어 있다(Jung, 2014; Kim, 2012; Kim, 2015). 더욱이 파생과 합성의 조건이나 투명 도에 따른 조건, 결합이나 분리과제의 특성에 따른 조건 등을 고려 해서 형태소인식능력의 특성을 깊이 있게 이해한 연구는 거의 없는 실정이다. 따라서 본 연구에서는 다양한 과제 유형에 따른 초등 저 학년기 아동들의 형태소인식능력의 특성을 좀더 깊이 있게 이해함 으로써 평가와 중재에 관한 임상적인 기초자료를 제시하고자 한다.

특히, 학령기에 들어선 다문화가정 아동 수가 늘어남에 따라 학 령기 다문화가정 아동의 언어 및 읽기 능력에 대한 관심이 늘어나 고 있다. 지금까지의 많은 연구에서 학령기 다문화가정 아동의 경 우 언어 및 읽기능력에 제한이 있는 것으로 나타났다(An, 2007; Kwon \& Seok, 2009; Pae \& Kim, 2010; Shim \& Jung, 2012). 초등학 교 저학년 다문화가정 아동들은 비다문화가정 아동들보다 낱말 해독과 덩이글 이해에서 낮은 수행력을 보인다고 보고하였으며(Pae \& Kim, 2010), 음운인식 능력이 비다문화가정 아동들보다 낮게 나 타났다(Kwon \& Seok, 2009). 또한 초등학교 1, 2학년 다문화가정 아동의 읽기 속도는 비다문화가정 아동보다 더 낮은 것으로 나타 났다(Shim \& Jung, 2012).

한편 다문화가정 아동을 대상으로 한 형태소인식능력을 살펴본 연구는 아직까지 없으며, 조사나 어미를 중심으로 한 문법형태소
사용능력과 관련된 선행연구가 있어왔다. Lee (2012)는 취학 전 다 문화가정 아동이 비다문화가정 아동보다 문법형태소 산출빈도가 더 낮았으며 오류율은 더 높은 것으로 나타났다. Kim (2009)의 연 구결과는 문법형태소 오류율, 오류 유형에 유의한 차이를 통해 학 령기 다문화가정 아동의 문법형태소 사용에 제한점을 시사했다. $\operatorname{Kim}$ 과 $\operatorname{Kim}$ (2011)은 다문화가정 아동의 주 양육자인 모의 언어가 문법형태소와 같은 통사영역을 충분히 지원하지 못하며, 이에 따라 비다문화가정 아동과 문법형태소 사용능력에 차이가 있을 수 있 음을 논의하였다. 이는 국내의 다문화가정 아동들이 주 언어로 한 국어를 사용하지만 주 양육자인 모의 언어에 영향으로 언어발달에 제한이 있음이 나타났고, 학령기로 성장하여서도 읽기능력 및 문 법형태소 사용의 제한을 보이는 것으로 밝혀졌다.

학령기 저학년 다문화가정 아동의 경우 학습관련 어휘 및 읽기 능력을 습득해 나가는 시기에 겪게 되는 어려움들에 음운인식이나 형태소인식능력과 같은 메타언어인식 능력이 영향을 미치는 것으 로 보인다(Kwon \& Seok, 2009). 이중언어 사용자를 대상으로 형태 소인식과 읽기에 연관성을 연구한 Marinova-Todd, Siegel과 Mazabel (2013)은 두 언어가 다른 형태학적 특징을 갖고 쓰기 체계가 다 르면 형태소인식은 제 1 언어가 제 2 외국어에 영향을 줄 수 있으며, 연 구결과 모국어의 형태학적 구조에 따라 영어에 형태소인식과 음운 인식 점수가 낮게 나타났다고 보고하였다.

지금까지 다문화가정아동들의 문법형태소 사용 능력에 대해서 는 많은 관심을 받아오고 있는데 반해, 이들의 조어 관련 형태소인 식능력에 대한 연구는 아직까지 국내 연구에서는 다루어지지 않고 있다. 더욱이 학령기에 들어서 학업과 관련된 고급한 언어 및 읽기 능력이 요구되는 시기에 문법형태소 및 메타언어능력의 제한점은 읽기 능력에 영향을 미칠 것으로 사료된다. 이에 본 연구는 초등 저 학년에 재학 중인 다문화가정 아동이 비다문화가정 아동과 비교했 을 때 형태소인식능력에 차이가 있는지를 살펴보고, 단어조건(합 성과 파생, 투명과 불투명, 결합과 분리)에 따라 두 집단이 어떤 특 성을 보이는지 살펴보고자 하였다. 또한 집단별 형태소인식능력과 읽기과제와의 상관관계도 알아볼 것이다.

\section{연구 방법}

\section{연구 대상}

이 연구는 1-3학년의 다문화가정 아동 13 명과 비다문화가정 아 동 13 명, 총 26 명을 대상으로 하였다. 다문화가정 아동은 모두 어머 니가 국외에서 이주하고 한국인 아버지를 둔 아동으로, 어머니의 결혼 전 국적은 몽골(1명), 중국(12명)이었다. 모든 아동은 한국에 
Table 1. Participants' characteristics

\begin{tabular}{|c|c|c|c|c|c|c|}
\hline \multirow{2}{*}{ No. } & \multicolumn{4}{|c|}{ Non-multicultural family } & \multicolumn{2}{|c|}{$\begin{array}{l}\text { Non-multicultural } \\
\text { family }\end{array}$} \\
\hline & Grade & Gender & $\begin{array}{l}\text { Nationality } \\
\text { of mother }\end{array}$ & $\begin{array}{l}\text { Use of mother } \\
\text { language }\end{array}$ & Grade & Gender \\
\hline 1 & 1 & $M$ & China & None & 1 & $M$ \\
\hline 2 & 1 & $\mathrm{~F}$ & Mongolia & None & 1 & $\mathrm{~F}$ \\
\hline 3 & 1 & $\mathrm{~F}$ & China & None & 1 & $\mathrm{~F}$ \\
\hline 4 & 1 & $\mathrm{~F}$ & China & None & 1 & $\mathrm{~F}$ \\
\hline 5 & 1 & $\mathrm{~F}$ & China & None & 1 & $\mathrm{~F}$ \\
\hline 6 & 1 & $\mathrm{~F}$ & China & None & 1 & $\mathrm{~F}$ \\
\hline 7 & 2 & M & China & None & 2 & M \\
\hline 8 & 2 & $\mathrm{~F}$ & China & None & 2 & $\mathrm{~F}$ \\
\hline 9 & 2 & $F$ & China & None & 2 & $\mathrm{~F}$ \\
\hline 10 & 3 & M & China & None & 3 & M \\
\hline 11 & 3 & $\mathrm{~F}$ & China & Very little & 3 & $\mathrm{~F}$ \\
\hline 12 & 3 & $\mathrm{~F}$ & China & None & 3 & $\mathrm{~F}$ \\
\hline 13 & 3 & $\mathrm{~F}$ & China & None & 3 & $\mathrm{~F}$ \\
\hline
\end{tabular}

서 태어나고 서울, 경기에 거주하며, 주 언어로 한국어를 습득하고 있었다. 아동은 수용·표현어휘력검사(Kim, Hong, Kim, Jang, \& Lee, 2009)에서 $10 \%$ ile 이상에 해당하고, 기초학력검사 읽기(Park, Kim, Song, Jung, \& Jung, 2008)에서 $25 \%$ ile 이상에 속하는 아동이 었다. 기초학력검사에서의 선별기준은 저성취모델(low achievement model)에서의 저성취 기준을 따랐다(Shaywitz, Fletcher, Holahan, \& Shaywitz, 1992). 또한 아동들은 어머니 및 교육기관의 교사로부 터 시각적, 청각적, 정서적, 신체적 문제가 없다고 보고된 아동이었다.

비다문화가정 아동은 양부모가 모두 한국인인 아동으로 해당 학년에 속하는 다문화가정 아동과 성별이 일치된 아동이었다. 아 동은 수용·표현어휘력검사(Kim et al., 2009)에서 $10 \%$ ile 이상에 해 당하고, 기초학력검사-읽기(Park et al., 2008)에서 25\%ile 이상에 속하는 아동이었다. 또한 아동들은 어머니 및 교육기관의 교사로 부터 시각적, 청각적, 정서적, 신체적 문제가 없다고 보고된 아동이 었다. 아동의 정보는 Table 1과 같다.

두 집단의 선별검사 수행력의 차이와 대상 아동의 연령에 대한 기술통계 및 독립표본 $t$-검정 결과는 Table 2 와 같다. $t$-검정 결과 두 집단은 연령 $(t=-1.250, p>.05)$, 수용어휘능력 $(t=-1.882, p>.05)$, 기 초학력검사-읽기 $(t=-.543, p>.05)$ 에서 차이가 유의하지 않았다.

\section{실험 방법}

연구 절차

본 연구에서 다문화가정 집단의 모든 검사는 연구자에 의하여 실시하였으며, 비다문화가정 집단의 검사는 연구자를 포함하여 전 공 교수 1 명과, 언어병리학과 대학원 석사생 1 명에 의해 실시되었다
Table 2. Descriptive statistics

\begin{tabular}{lccr}
\hline Variable & $\begin{array}{c}\text { Multicultural } \\
\text { family }(\mathrm{N}=13)\end{array}$ & $\begin{array}{c}\text { Non-multicultural } \\
\text { family }(\mathrm{N}=13)\end{array}$ & $t(p$-value) \\
\hline Age (yr) & $7.91(0.76)$ & $8.34(0.97)$ & $-1.250(.223)$ \\
REVT-raw score & $99.3(15.8)$ & $113.0(20.9)$ & $-1.882(.072)$ \\
KISE-BAAT (reading score) & $82.9(9.0)$ & $85.3(13.0)$ & $-.543(.592)$ \\
\hline
\end{tabular}

Values are presented as mean (SD).

REVT = receptive \& expressive vocabulary test (Kim, Hong, Kim, Jang, \& Lee, 2009); KISE-BAAT = Korean Institute for Special Education-Basic Academic Achievement Test (Park, Kim, Song, Jung, \& Jung, 2008).

검사에 참여한 모든 검사자는 사전에 각 검사의 검사절차 및 실시 방법, 채점방법에 대한 훈련을 받았으며, 실제 검사과정을 연습한 후 본 검사를 실시하도록 하였다. 본 검사는 아동의 집을 개별 방문 하여 조용한 방에서 실시하며 한 명의 검사자가 한 명의 아동을 개 별적으로 실시하였다. 과제 순서에 의한 효과를 최소화하기 위해 어휘와 형태소인식과제를 먼저하고, 기초학력검사를 나중에 하거 나 그 반대의 순서로 실시하였다. 형태소인식과제는 합성어 결합과 제, 파생어 결합과제, 합성어 분리과제, 파생어 분리과제의 순서대 로 제시하였다. 각 과제가 시작될 때마다 과제실시 방법에 대한 지 시문과 예문을 제시하여, 아동이 과제를 이해하는지 확인한 후 본 과제를 실시하였다. 예를 들어 파생어 분리과제의 경우 "이제부터 선생님이랑 낱말 나누기 놀이를 할 거에요. 주어진 낱말을 조금 바 꿔서 ( )를 채우세요. 괄호 안에 들어갈 낱말은 주어진 낱말을 이용 해서 생각해야 해요.”라고 지시한 후 “마당쇠. 우리집 ( )에 예쁜 꽃 이 피어 있다.”의 예문을 주고, ( )안에 낱말을 적어 넣을 수 있도록 연습하였다.

연구 도구

아동선별 검사도구

수용·표현어휘력검사(REVT): 두 집단 아동의 어휘 이해 능력이 정상발달 범주임을 확인하기 위해 수용·표현어휘력검사(Kim et al., 2009) 중 수용어휘력 검사를 실시하였다.

기초학력검사(KISE-BAAT): 두 집단 아동의 읽기 능력이 정상 발달 범주임을 확인하기 위해 기초학력검사(Park et al., 2009) 중 읽 기 검사를 실시하였다.

본 검사도구

형태소인식능력검사: 형태소 인식능력 측정을 위한 검사는 선행 연구(Apel, Diehm, \& Apel, 2013)의 합성 및 파생어 과제를 참고하 여 Jung (2014)가 개발한 과제를 사용하였다. Jung (2014)는 형태소 인식과제에 사용된 문항은 초등학교 1-6학년 읽기 교과서에 고빈 
도로 나타난 합성어와 파생어 단어를 분석하여 사용하였고, 특히 저학년부터 고빈도로 나타난 단어를 중심으로 구성하였다. 합성어 항목은 두 개의 어근을 합성하여 새로운 단어를 만드는 과제 20 문 항(예: “종이로 만든 컵을 종이컵이라고 하지요. 고무로 만든 컵은 뭐라고 할까요?”)과 합성어를 분리하여 주어진 문장의 빈칸에 알 맞은 단어를 삽입하는 과제 20문항(예: "눈물. ( )이 나빠서 글씨 가 잘 안 보인다.”)으로 구성되어 있다. 파생어 항목은 어근을 포함 한 단어를 주고 주어진 문장의 괄호 안에 적절한 접사를 붙여 파생 어를 만들어 넣는 과제로 어근과 접사를 결합하는 과제 20 문항(예: “과학. 지성이의 꿈은 커서 ( ) 가 되는 것이다"), 파생어를 분리하 여 주어진 문장의 빈칸을 채우는 과제 20문항(예: "하느님. 비가 개 고 나니 ( )이 아주 맑다”)으로 구성되었다. 또한 네 가지 유형의 과제 20 문항 중에서 10 문항은 음운론적 또는 형태론적 투명도가 높은 단어로 기본단어의 발음이나 형태가 변하지 않는 문항(예: '지 우다'를 '지우개'로 바꾸는 문항)으로 구성되며, 나머지 10 문항은 음운론적 또는 형태론적 투명도가 낮은 단어로 기본 단어의 발음 이나 철자가 변하는 문항(예: ‘바늘'을 바느질'로 바꾸게 되며 이때 'ㄹ' 탈락 규칙을 적용하는 문항)으로 구성되었다. 형태소인식과제 는 언어치료 전공 교수 1 인, 언어치료전공 박사수료자 2 인 총 세 명 의 언어치료전문가에 의해 내용 타당도를 검증 받았다. 타당도는 1-5점 척도(매우 부적절, 부적절, 보통, 적절, 매우 적절)로 평가하였 으며, 평가결과 4.69 로 나타났다.

한국 언어기반 읽기검사(KOLRA): 읽기능력을 측정하기 위해 한국 언어기반 읽기검사(Korea Language-based Reading Assessent; Pae, Kim, Yoon, \& Jahang, 2015)의 하위항목 중 해독, 읽기 유창성, 읽기이해 검사를 실시하였다.

\section{자료 분석}

형태소인식능력 평가에 대한 채점 기준은 한 문항당 1 점씩 총 80 점을 만점으로 하여 채점되었으며, 과제 유형에 따라 분리과제, 산 출과제, 투명과제, 불투명과제로 나누어 자료를 분석하였다. 또한 오류유형을 살펴보기 위하여 오류유형을 8가지(첨가, 탈락규칙미 적용, 생략, 대치, 무관한 답, 제시어반복, 철자, 기타)로 분류하여 오

Table 3. $t$-test of total morphological awareness scores by group

\begin{tabular}{lccc}
\hline Variable & $\begin{array}{c}\text { Multicultural family } \\
(\mathrm{N}=13)\end{array}$ & $\begin{array}{c}\text { Non-multicultural } \\
\text { family }(\mathrm{N}=13)\end{array}$ & $t(p$-value) \\
\hline $\begin{array}{c}\text { Morphological } \\
\text { awareness }\end{array}$ & $58.23(7.44)$ & $64.84(6.63)$ & $-2.393^{*}(.025)$ \\
\hline
\end{tabular}

Values are presented as mean (SD). ${ }^{*} p<.05$.
류율을 분석하였다. 오류율은 오류유형별 오류 수/총 오류 수로 계 산하였다. 오류유형의 예는 Appendix 1에 제시되어 있다.

\section{자료 처리}

검사에서 수집된 데이터는 SPSS 18.0을 사용하여 분석했다. 다 문화가정 아동과 비다문화가정 아동의 선별검사 과제의 차이, 형 태소인식능력의 차이, 과제 유형에 따른 형태소인식능력의 차이, 오 류유형의 차이를 알아보기 위해 $t$-검정을 실시하였다. 또한, 다문화 아동과 비다문화아동의 형태소인식능력과 읽기과제와의 상관관 계를 알아보기 위해 피어슨 상관분석을 실시하였다.

\section{연구 결과}

\section{다문화가정 아동과 일반아동의 형태소인식능력}

집단에 따른 형태소인식능력을 알아보기 위한 기술통계 및 독립 표본 $t$-검정을 실시한 결과는 Table 3 과 같다. 독립표본 $t$-검정 결과 다문화가정 집단과 비다문화가정 집단 간의 형태소인식능력은 통 계적으로 유의한 차이가 나타났으며 $(t=-2.393, p<.05)$, 다문화가 정 아동이 비다문화가정 아동보다 형태소인식능력 점수가 낮은 것 으로 나타났다.

\section{투명·불투명 과제별 형태소인식능력}

집단과 과제유형별 형태소인식능력을 알아보기 위한 기술통계 및 독립표본 $t$-검정을 실시한 결과는 Table 4 와 같다. 독립표본 $t$-검 정 결과 투명과제에 대한 두 집단 간 과제 수행력은 통계적으로 유 의한 차이가 나타나지 않았으나 $(t=-1.995, p>.05)$, 불투명과제에 대한 두 집단 간의 과제 수행력은 통계적으로 유의한 차이가 나타 났다 $(t=-2.404, p<.05)$.

\section{합성·파생 과제별 형태소인식능력}

집단과 과제유형별 형태소인식능력을 알아보기 위한 기술통계 및 독립표본 $t$-검정을 실시한 결과는 Table 5 와 같다. 독립표본 $t$-검 정 결과 합성과제에 대한 두 집단 간 과제 수행력에서는 통계적으

Table 4. Comparison of morphological awareness in transparent and opaque type tasks

\begin{tabular}{lccr}
\hline Variable & $\begin{array}{c}\text { Multicultural family } \\
(\mathrm{N}=13)\end{array}$ & $\begin{array}{c}\text { Non-multicultural } \\
\text { family }(\mathrm{N}=13)\end{array}$ & $t(p$-value) \\
\hline Transparent type & $32.15(3.38)$ & $34.53(2.66)$ & $-1.995(.058)$ \\
Opaque type & $26.07(4.46)$ & $30.15(4.18)$ & $-2.404^{*}(.024)$ \\
\hline $\begin{array}{l}\text { Values are presented as mean (SD). } \\
{ }^{*} p<.05 .\end{array}$ & & \\
& & & \\
\end{tabular}


Table 5. Comparison of morphological awareness in compound and derivative type tasks

\begin{tabular}{lccc}
\hline Variable & $\begin{array}{c}\text { Multicultural family } \\
(\mathrm{N}=13)\end{array}$ & $\begin{array}{c}\text { Non-multicultural } \\
\text { family }(\mathrm{N}=13)\end{array}$ & $t(p$-value) \\
\hline Compound type & $31.38(3.70)$ & $34.23(4.16)$ & $-1.840(.078)$ \\
Derivative type & $26.84(3.93)$ & $30.46(3.82)$ & $-2.377^{*}(.026)$ \\
\hline
\end{tabular}

Values are presented as mean (SD).

${ }^{*} p<.05$.

Table 6. Comparison of morphological awareness in combination type separation type tasks

\begin{tabular}{lccr}
\hline Variable & $\begin{array}{c}\text { Multicultural family } \\
(\mathrm{N}=13)\end{array}$ & $\begin{array}{c}\text { Non-multicultural } \\
\text { family }(\mathrm{N}=13)\end{array}$ & $t(p$-value $)$ \\
\hline Combination type & $26.15(4.74)$ & $30.53(4.38)$ & $-2.447^{*}(.022)$ \\
Separation type & $32.07(4.00)$ & $34.15(3.67)$ & $-1.378(.181)$ \\
\hline
\end{tabular}

Values are presented as mean (SD).

${ }^{*} p<.05$.

로 유의한 차이가 나타나지 않았으나 $(t=-1.840, p>.05)$, 파생과제 에 대한 두 집단 간의 과제 수행력에서는 통계적으로 유의한 차이 가 나타났다 $(t=-2.377, p<.05)$.

\section{결합· 분리 과제별 형태소인식능력}

집단과 과제유형별 형태소인식능력을 알아보기 위한 기술통계 및 독립표본 $t$-검정을 실시한 결과는 Table 6 과 같다. 독립표본 $t$-검 정 결과 결합과제에 대한 두 집단 간 과제 수행력은 통계적으로 유 의한 차이가 나타났다 $(t=-2.447, p<.05)$. 그러나 분리과제에 대한 두 집단 간의 과제 수행력은 통계적으로 유의한 차이가 나타나지 않았다 $(t=-1.378, p>.05)$.

\section{형태소인식능력 과제의 오류 유형}

두 집단의 형태소인식능력 평가의 오류 유형에 따른 오류율의 차 이를 알아보기 위한 기술통계 및 독립표본 $t$-검정을 실시한 결과는 Table 7과 같다. 기술통계 결과 다문화가정 집단은 제시어반복오류 $>$ 대치오류>무응답오류 순으로 오류율이 높았으며, 비다문화가 정 집단은 대치오류>제시어반복오류>무응답오류 순으로 오류 율이 높았다. 두 집단 모두 오류율이 가장 낮은 오류유형은 기타오 류였다. 두 집단의 오류유형별 차이를 알아보기 위해 독립표본 $\mathrm{t}$-검 정을 실시한 결과, 두 집단은 오류유형 중 첨가 $(t=-2.683, p<.05)$ 와 대치오류 $(t=-1.134, p<.05)$ 에서 통계적으로 유의한 차이가 나 타났다. 그러나 그 밖에 오류유형인 생략, 탈락규칙미적용, 반복, 무 관한 답, 철자, 무응답, 기타에서는 두 집단 간의 유의한 차이가 나 타나지 않았다.
Table 7. Comparison of error types

\begin{tabular}{lccr}
\hline & $\begin{array}{c}\text { Multicultural } \\
\text { family }(\mathrm{N}=13)\end{array}$ & $\begin{array}{c}\text { Non-multicultural } \\
\text { family }(\mathrm{N}=13)\end{array}$ & \multicolumn{1}{c}{$t$ (p-value) } \\
\hline Addition & $6.743(4.827)$ & $15.210(10.304)$ & $-2.683^{*}(.011)$ \\
Non-transformation error & $10.050(5.852)$ & $4.962(5.318)$ & $2.320(.879)$ \\
Ellipsis & $7.264(5.658)$ & $4.350(5.934)$ & $1.281(.831)$ \\
Replacement & $22.220(7.771)$ & $28.418(18.102)$ & $-1.134^{*}(.020)$ \\
Unrelated answer & $9.218(11.173)$ & $5.062(7.131)$ & $1.131(.238)$ \\
Double use error & $27.574(10.985)$ & $27.417(12.353)$ & $1.343(.216)$ \\
Spelling & $3.929(5.581)$ & $3.571(5.292)$ & $.168(.983)$ \\
No response & $12.468(11.907)$ & $16.616(17.151)$ & $-.716(.173)$ \\
Others & $.498(1.219)$ & $.384(1.386)$ & $.222(.743)$ \\
\hline
\end{tabular}

Values are presented as mean (SD).

${ }^{*} p<.05$.

Table 8. Correlations between the RA scores and MA

\begin{tabular}{lccll}
\hline & \multicolumn{3}{c}{ RA } \\
\cline { 3 - 5 } & & Decoding & RF & RC \\
\hline Multicultural family & MA & $.58^{*}$ & $.72^{* *}$ & $.64^{*}$ \\
Non-multicultural family & MA & $.76^{* *}$ & $.56^{*}$ & $.73^{* *}$ \\
\hline
\end{tabular}

$\mathrm{MA}=$ morphological awareness; $\mathrm{RA}=$ reading ability; $\mathrm{RF}=$ reading fluency; $\mathrm{RC}=$ reading comprehension.

${ }^{*} p<.05,{ }^{* *} p<.01$.

\section{형태소인식능력과 읽기능력}

다문화가정 아동 집단과 비다문화가정 아동 집단의 형태소인식 능력과 읽기과제 간의 상관분석 결과는 Table 8과 같다. 상관관계 분석 결과 두 집단 아동 모두의 형태소인식능력은 모든 읽기 관련 변인과 유의미한 상관관계가 나타났다.

\section{논의 및 결론}

본 연구에서는 초등학교 1-3학년 다문화 가정 아동과 비다문화 가정 아동의 형태소인식능력에 차이를 알아보고자 하였다.

연구 결과 두 집단 간의 형태소인식능력 과제 수행력에는 통계적 으로 유의미한 차이가 있었으며 $(t=-2.393, p<.05)$, 다문화가정 아 동이 비다문화가정 아동에 비하여 형태소인식능력 과제의 수행력 이 더 낮은 것으로 나타났다. 이러한 연구결과는 다문화가정 아동 의 문법형태소 사용능력에 대한 $\operatorname{Kim}$ (2009), Kim과 Kim (2011)의 연구결과와 연관 지어 해석해 볼 수 있다. Kim (2009)은 초등학교 저학년 다문화가정 아동의 문법형태소 연구결과 다문화가정 아동 이 비다문화가정 아동에 비하여 문법형태소 사용에 있어서 제한 이 있음을 보고하였다. 또한 Kim과 $\operatorname{Kim}$ (2011)은 비다문화가정 아 동과 언어와 지능, 학습능력을 일치시킨 다문화가정 아동이 문법 
성 판단과제에서 수행력이 낮다고 하였다. 이와 관련하여 본 연구 결과는 다문화가정 아동이 문법형태소 사용 및 문법적 적절성을 판단하는 메타언어인식능력과 마찬가지로 형태소인식능력에서도 비다문화가정 아동에 비하여 제한이 있음을 시사한다. 특히 본 연 구에서는 다문화가정 아동이 비다문화가정 아동과 수용어휘 및 읽기 능력에 능력에 차이가 없었음에도 불구하고 비다문화가정 아 동보다 수행력이 낮은 것으로 나타났다. 이는 수용어휘를 일치시킨 학령기 다문화가정 아동의 동음이의어 습득이 비다문화가정 아동 들과 차이가 난다는 연구결과와도 관련지어 해석해 볼 수 있다 (Kwak, 2012). 즉, 표준화된 검사로 이루어진 언어능력의 양적인 측 정에서는 차이가 나지 않더라도 메타언어적 차원이나 질적인 측면 에서의 언어능력을 습득하는 데 있어 다문화가정 아동들이 제한 점이 있을 수 있음을 시사해준다.

형태소인식능력 과제 유형에 따른 두 집단 간 차이를 살펴본 결 과 다문화가정 아동이 불투명한 과제에서는 통계적으로 유의미하 게 비다문화가정 아동보다 수행력이 낮은 것으로 나타났으나, 투명 한 과제에서는 차이가 나지 않았다. 이러한 결과는 아동과 성인 집 단 모두 음운적, 철자적으로 불투명한 단어보다 투명도가 높은 단 어를 읽을 때, 정확도와 속도 면에서 수행력이 더 높다고 보고한 선 행연구(Carlisle, 1995; Weismer et al., 2000)를 지지한다. 본 연구에 서도 두 집단 모두 투명한 과제에서 수행력이 더 높았고, 투명과제 에서는 집단 간 차이가 나지 않았다. 하지만 불투명한 과제에서는 다문화가정 아동의 수행력이 더 낮게 나타났다. 이러한 연구결과는 다문화가정 아동들이 표준화된 읽기 검사에서 차이가 없어도 불 투명한 단어나 파생어에서 형태소를 조작하는 데는 어려움이 있다 는 것을 말해준다. 이는 다문화가정 아동의 읽기 능력을 평가하고 중재할 때, 과제의 난이도를 고려한 접근이 필요함을 시사해 준다.

이러한 연구결과는 형태적으로 불투명한 문항이 형태적으로 투 명한 문항에 비해 형태소인식에 주요 변수임을 밝힌 McCutchen, Green과 Abbott (2008)의 연구를 뒷받침한다. 아동이 불투명한 단 어를 읽기 위해서는 다음절 단어에 대한 음운적 인식, 단어를 이루 고 있는 잠재적인 구성단위의 인식, 그리고 단어가 음운적, 철자적 으로 변화하는 것을 맵핑하는 능력이 요구된다. 예를 들어 signature라는 단어를 읽을 때 아동은 sign이라는 단어를 연상하게 되고 이때 그 두 단어가 갖는 형태에 대한 반응경쟁(response competition)이 발생하게 되어 어려움을 겪게 된다(McCutchen et al., 2008). 또한 불투명과제의 경우 음운변화에 있어 형태론과 음운론적 요 소에 대한 동시적 처리가 요구된다. 다형태소가 결합된 고급 단어 노출은 제한된 환경에 있는 다문화가정 아동이 투명한 단어를 처 리하는 것에 어려움이 없지만 불투명한 단어를 처리하는 과정에서
발생하는 반응경쟁에 대하여 어려움이 있는 것으로 판단된다. 이 는 학령기 다문화가정 아동의 형태소인식능력 평가에 있어 투명한 과제보다 불투명한 과제가 더 변별력이 높은 유형임을 시사한다.

다음으로 합성어·파생어에 따른 수행력 차이를 살펴본 결과 다 문화가정 아동과 비다문화가정 아동은 두 과제 유형 중 파생어 과 제 유형에서 통계적으로 유의미한 차이가 있었으며, 합성어 과제에 서는 차이가 없었다. 본 연구 결과 두 집단의 아동들이 파생어 과제 에서 더 수행력이 낮았던 것은 아동들이 형태소인식에 있어서 단 어의 어원에서 파생되어진 형태가 요구되는 과제를 더 어려워 한다 는 McCutchen 등(2008)의 연구와 일치하는 것으로 나타났다.

선행 연구에 따르면 학년이 낮은 아동들의 경우 익숙한 단어로 이루어진 어근의 결합보다는 어근에 노출빈도가 낮은 접사를 분리 하거나 결합시키는 파생어 인식이 더 어렵고 늦게까지 발달하는 능 력이라고 한다(Goodwin et al., 2012). 이 과제를 수행하기 위해서 는 제시어를 보고 문맥에 맞게 형태소에 알맞은 접사를 결합하거 나 분리하여 정답을 예측하는 처리 능력이 필요한데, 이 과정에서 접사의 의미를 파악해서 처리해야 하는 부담이 합성어에 비해 더 크기 때문이다. 이 연구에서는 두 집단 아동 모두 합성어과제보다 파생어 과제 수행력이 더 낮은 것으로 나타나 선행연구의 결과를 지지해주고 있다. 그런데 다문화가정 아동이 비다문화가정 아동과 합성어에서는 수행력 차이가 없었음에도 파생어 과제에 있어서 비 다문화가정 아동들보다 수행력이 낮았다. 이 연구결과는 다문화가 정 아동이 비교적 익숙한 단어로 이루어진 어근의 결합보다 접사 의 의미를 인식하고 활용해야 하는 어휘습득에 제한이 있을 수 있 음을 시사해준다. 따라서 본 연구 결과에서 학령기가 되었음에도 불구하고 다문화가정 아동이 비다문화가정의 아동보다 파생어에 대한 수행력 낮았다는 것은 다문화 가정 아동이 비다문화가정 아 동에 비하여 파생어를 인식하는 능력에 발달이 더 느리며, 이로 인 한 한국어의 활용 능력과 언어를 학습하는 것에 대하여 어려움이 있을 수 있음을 시사한다. 또한 이는, 향후 후속 연구를 통해 다문 화가정 아동에 파생어 능력과 언어 학습에 관한 관계를 좀 더 면밀 히 연구될 필요가 있다.

결합·분리 과제에 따른 수행력 차이를 살펴본 결과 다문화가정 아동과 비다문화가정 아동은 두 과제 유형 중 결합 과제 유형에서 통계적으로 유의미한 차이가 있었으며, 분리과제에서는 차이가 없 었다. 본 연구에서 사용한 결합과제는 제시어에서 목표 형태소를 인식하여 문항에 맞게 형태소에 새로운 형태소를 결합하거나 변형 시켜 정답을 산출하는 과제였다. 반면 분리 과제는 제시어에서 목 표 형태소를 분리해내어 문맥에 맞게 단어를 변형시키는 과제였다. 예를 들어 결합과제는 제시어 '지우다'를 보고 문맥에 맞는 단어로 
데는 다소 제한점이 있음을 고려해서 해석해야 할 것이다.

\section{REFERENCES}

Ahn, S. W., Heo, M. J., \& Seo, J. H. (2012). A study on a phonological awareness of preschoolers in South Korea: exploring the effects of letter knowledge, letter-sound correspondence, ages, and working memory on the phonological awareness. Journal of Speech-Language and Hearing Disorders, 21, 365-388

An, W. S. (2007). Study on the expressive skills of children from international marriages (Master's thesis). Korean National University of Education, Cheongju, Korea.

Apel, K., Diehm, E., \& Apel, L. (2013) Using multiple measures of morphological awareness to assess its relation to reading. Topics in Language Disorders, 33, 42-56.

Berninger, V. W., Abbott, R. D., Nagy, W., \& Carlisle, J. (2010). Growth in phonological, orthographic, and morphological awareness in grades 1 to 6 . Journal of Psycholinguistic Research, 39, 141-163.

Carlisle, J. F. (1987). The use of morphological knowledge in spelling derived forms by learning-disabled and normal students. Annals of Dyslexia, 37, 90-108.

Carlisle, J. F. (1988). Knowledge of derivational morphology and spelling ability in fourth, sixth, and eighth graders. Applied Psycholinguistics, 9, 247-266.

Carlisle, J. F. (1995). Morphological awareness and early reading achievement. In L. B. Feldman (Ed.), Morphological aspects of language processing (pp. 189-209). Hillsdale, NJ: Lawrence Erlbaum Associates.

Carlisle, J. F., \& Stone, C. (2005). Exploring the role of morphemes in word reading. Reading Research Quarterly, 40, 428-449.

Cho, M. (2003). Psychology of language. Seoul: Hakjisa.

Deacon, S. H., \& Kirby, J. R. (2004). Morphological awareness: just "more phonological"? The roles of morphological and phonological awareness in reading development. Applied Psycholinguistics, 25, 223-238.

Fowler, A. E., \& Liberman, I. Y. (1995). The role of phonology and orthography in morphological awareness. In L. B. Feldman (Ed.), Morphological aspects of language processing (pp. 57-188). Hillsdale, NJ: Lawrence Erlbaum Associates.

Gillon, G. T. (2004). Phonological awareness: from research to practice. New York, NY: Guilford Press.

Goodwin, A. P., Huggins, A. C., Carlo, M., Malabonga, V., Kenyon, D., Louguit, M., \& August, D. (2012). Development and validation of extract the 
base: an English derivational morphology test for third through fifth grade monolingual students and Spanish-speaking English language learners. Language Testing, 29, 265-289.

Hwang, M. (2003). The production grammatical morphemes of Korean children with developmental language impairments. Speech Sciences, 10, 4764.

Hwang, S., \& Jeong, O. (2008). Language characteristics of children from culturally diverse family environments. Korean Journal of Communication and Disorders, 13, 174-192.

Jarmulowicz, L., Taran, V. L., \& Hay, S. E. (2007). Third graders' metalinguistic skills, reading skills, and stress production in derived English words. Journal of Speech, Language, and Hearing Research, 50, 1593-1605.

Jung, K. H. (2014). Morphological awareness and reading ability of schoolaged children from grades 1 to 3. Communication Sciences and Disorders, 19, 21-30.

Jung, K., \& Pae, S. (2010). The grammaticality judgment in school-aged children with specific language impairment. Korean Journal of Communication Disorders, 15, 617-631.

Kim, E., \& Kim, H. (2011). Comparison on grammaticality judgement and error correction abilities between children in ordinary and in multicultural families. Journal of Special Education \& Rehabilitation Science, 50, 131148.

Kim, K. (2012). Relations between literacy and morphological awareness in kindergarten children (Master's thesis). Kyungnam University, Changwon, Korea.

Kim, M. (2014). A Korean literature review of metalinguistic skills in semantics and grammar. Journal of Speech and Hearing Disorders, 23, 61-77.

Kim, N. (2009). Use of grammatical morphemes of Korean lower graders with multicultural background (Master's thesis). Hallym University, Chuncheon, Korea.

Kim, S. (2014). Morphological awareness and reading ability for 1 to 3 grades elementary school students from poor readers (Master's thesis). Yongin University, Yongin, Korea.

Kim, Y. (2011). Linguistic performance of Korean children from low SES multicultural families. Journal of Speech \& Hearing Disorders, 20, 73-88.

Kim, Y. T., Hong, G. H., Kim, K. H., Jang, H. S., \& Lee, J. Y. (2009). Receptive \& expressive vocabulary test (REVT). Seoul: Seoul Community Rehabilitation Center.

Korea Ministry of Government Administration and Home Affairs. (2014). Present-condition investigation of foreign population. http://www.moga-
ha.go.kr/frt/bbs/type001/commonSelectBoardArticle.do?bbsId=BBSMST R_000000000014\&nttId=42492.

Kuo, L. J., \& Anderson, R. C. (2006). Morphological awareness and learning to read: a cross-language perspective. Educational Psychologist, 41, 161-180.

Kwak, S. (2012). A study on comprehension ability of homonym for 3, 4 grade students from multicultural family (Master's thesis). Yongin University, Yongin, Korea.

Kwon, M., \& Seok, D. (2009). The meta language characteristics of children from multicultural families. Journal of Speech and Hearing Disorders, 18, 139-150.

Kwon, M., \& Seok, D. (2010). The comparison of metalinguistic ability between children from multicultural families and non-multicultural families in terms of phonological processing. Journal of Speech and Hearing Disorders, 19, 1-23.

Lee, K. (2012). The use of grammatical morpheme in preschool aged children in multicultural family background (Master's thesis). Nambu University, Gwangju, Korea.

Marinova-Todd, S. H., Siegel, L. S., \& Mazabel, S. (2013). The association between morphological awareness and literacy in English language learners from different language backgrounds. Topics in Language Disorders, 33, 93-107

McCutchen, D., Green, L., \& Abbott, R. (2008). Children's morphological knowledge: links to literacy. Reading Psychology, 29, 289-314.

Nagy, W. E., \& Anderson, R. C. (1995). Metalinguistic awareness and literacy acquisition in different languages (Center for the Study of Reading Technical Report, No. 618). Champaign, IL: University of Illinois at Urbana-Champaign.

Nation, K., \& Snowling, M. J. (2004). Beyond phonological skills: broader language skills contribute to the development of reading. Journal of Research in Reading, 27, 342-356.

Pae, S., \& Kim, M. (2010). Language based reading abilities of Korean schoolaged children with multicultural backgrounds. Korean Journal of Communication Disorders, 15, 146-156.

Pae, S., Kim, M., Yoon, H., \& Jahang, S. (2015). Korean Language-based Reading Assessment. Seoul: Hakjisa.

Park, G., Kim, G., Song, Y., Jung, D., \& Jung, I. (2008). Korean Institute for Special Education-Basic Academic Achievement Test (KISE-BAAT). Ansan: Korean Institute for Special Education.

Shankweiler, D., Crain, S., Katz, L., Fowler, A. E., Liberman, A. M., Brady, S. A., ... Shaywitz, B. A. (1995). Cognitive profiles of reading-disabled chil- 
Eun Ha Kim, et al. • Morphological Awareness of School-Aged Children from Multicultural Families

dren: comparison of language skills in phonology, morphology, and syntax. Psychological Science, 6, 149-156.

Shaywitz, B. A., Fletcher, J. M., Holahan, J. M., \& Shaywitz, S. E. (1992). Discrepancy compared to low achievement definitions of reading disability results from the Connecticut longitudinal study. Journal of Learning Disabilities, 25, 639-648.

Shim, G., \& Jung, K. (2012). Reading fluency of first and second grade chil- dren from multicultural backgrounds. Journal of Speech \& Hearing Disorders, 21, 93-110.

Weismer, S. E., Tomblin, J. B., Zhang, X., Buckwalter, P., Chynoweth, J. G., \& Jones, M. (2000). Nonword repetition performance in school-age children with and without language impairment. Journal of Speech, Language, and Hearing Research, 43, 865-878. 
Appendix 1. 오류유형에 대한 조작적 정의

\begin{tabular}{|c|c|c|c|}
\hline 오류유형 & 조작적 정의 & 검사문항의 예 & 반응의 예 \\
\hline 첨가 & 목표 형태소의 음소 또는 음절 일부에 다른 형태소를 첨가하여 작성한 경우 & $\begin{array}{l}\text { 돌로 만든 담을 돌담이라고 합니다. } \\
\text { 풀로 담을 만들면 뭐라고 할까요? }\end{array}$ & 풀담이(풀담) \\
\hline $\begin{array}{l}\text { 탈락규칙 } \\
\text { 미적용 }\end{array}$ & 목표 형태소의 탈락규칙을 적용하지 않고 작성한 경우 & $\begin{array}{c}\text { 밀고 닫는 것을 미닫이라고 합니다. } \\
\text { 열고 닫는 것은 뭐라고 할까요? }\end{array}$ & 열닫이(여닫이) \\
\hline 생략 & 목표 형태소의 음소 또는 음절 일부를 생략한 경우 & 장난전화에 새벽부터 경찰들이 ( )했다. & 고생(헛고생) \\
\hline 대치 & 목표 형태소의 음소 또는 음절 일부를 다른 형태소로 바꾸어 작성한 경우 & 이 숙제를 다 하려면 ( )이(가) 걸린다. & 이튿(이틀) \\
\hline 무관한 답 & 목표 형태소와 전혀 관련이 없는 어휘로 작성한 경우 & 엄마의 잔소리는 참기가 $(\quad$ ). & 막히다(고통스럽다) \\
\hline \multicolumn{4}{|c|}{ 제시어 반복오류 제시된 어휘와 동일하게 작성하는 경우 } \\
\hline 철자 & 목표 형태소의 음소 또는 음절 일부의 철자를 틀리게 작성한 경우 & 지성이는 글씨가 틀려서 ( )(으)로 지웠다. & 지우게(지우개) \\
\hline 무응답 & 정답을 작성하지 않은 경우 & & \\
\hline 기타 & 위의 내용에 포함되지 않는 경우 & 옷이 얇아서 ( )를 견디기가 힘들다. & $\begin{array}{l}\text { 문밖으로 나가면 } \\
\text { 춥다(추위) }\end{array}$ \\
\hline
\end{tabular}




\section{국문초록}

\section{초등 1-3학년 다문화가정 아동의 형태소인식능력}

김은하 · 정경희

용인대학교 재활복지대학원 언어재활학과

배경 및 목적: 본 연구는 학령기 1-3학년 다문화가정 아동과 비다문화가정 아동의 형태소인식능력의 차이를 밝히는 것을 목적으로 하 였다. 방법: 본 연구에서는 다문화가정 아동 13 명과 비다문화가정 아동 13 명을 대상으로 형태소인식능력을 평가하고 정반응의 빈도와 오류에 따른 특성을 비교 분석하였다. 또한 형태소인식능력과 읽기과제(해독, 읽기유창성, 읽기이해)와의 상관관계를 알아보았다. 결 과: 본 연구 결과 첫째, 다문화가정 아동은 비다문화가정 아동과 형태소인식능력에 유의한 차이가 있었으며 수행력이 더 낮았다. 둘째, 다문화가정 아동과 비다문화가정 아동은 형태소인식능력 평가에서 오류유형에 따른 차이가 나타났다. 두 집단은 첨가와 대치오류유 형에서 통계적으로 유의한 차이가 나타났으며 다문화가정 아동이 더 많은 오류를 보였다. 셋째, 다문화가정 아동의 형태소인식능력은 모든 읽기 능력과 상관이 있는 것으로 나타났다. 논의 및 결론: 다문화가정 아동은 수용어휘력과 기초학습능력-읽기에서 정상발달 수 준임에도 불구하고 비다문화가정 아동에 비해 형태소인식 과제 수행력에 제한이 있는 것으로 나타났다.

핵심어: 다문화가정, 형태소인식능력, 학령기아동, 투명도, 파생어

본 연구는 제1저자의 석사학위논문(2015)을 수정, 발췌한 것임.

\section{참고문헌}

곽신실(2012). 초등학교 3,4학년 다문화가정 아동의 동음이의어 이해력 연구. 용인대학교대학원 석사학위논문.

권미지, 석동일(2009). 다문화가정 아동의 메타언어 특성. 언어치료연구, 18, 139-150.

권미지, 석동일(2010). 다문화가정 아동과 일반아동 간 음운처리에 관한 메타언어능력의 비교 분석. 언어치료연구, 19, 1-23.

김기예 (2012). 유치원 아동의 형태소인식 능력과 문식성 간의 관계. 경남대학교대학원 석사학위 논문.

김나영(2009). 초등학교 저학년 다문화가정 아동의 문법형태소사용특성. 한림대학교대학원 석사학위논문.

김미배(2014). 의미, 문법 영역에서 상위언어능력에 대한 국내 문헌연구. 언어치료연구, 23, 61-77.

김순호(2014). 학령기 읽기부진 아동과 일반아동의 형태소인식능력 비교. 용인대학교대학원 석사학위논문.

김영란(2011). 취학전 저소득층 다문화가정 아동의 언어능력. 언어치료연구, 20, 73-88.

김영태, 홍경훈, 김경희, 장혜성, 이주연(2009). 수용·표현어휘력검사(REVT). 서울: 서울장애인종합복지관.

김은정, 김화수(2011). 다문화가정 아동과 일반 아동의 문법성 판단 및 오류수정 비교연구. 특수교육재활과학연구, 50, 131-148.

박경숙, 김계옥, 송영준, 정동영, 정인숙(2008). 기초학력검사. 안산: 국립특수교육원.

배소영, 김미배(2010). 초등 저학년 다문화가정 아동의 읽기와 언어. 언어청각장애연구, 15, 146-156.

배소영, 김미배, 윤효진, 장승민(2015). 언어기반읽기평가. 서울: 학지사.

심고우니, 정경희 (2012). 초등학교 1-2학년 다문화가정 아동의 읽기 유창성 특성. 언어치료연구, 21, 93-110.

안성우, 허민정, 서중현(2012). 학령전기 유아의 음운인식능력에 관한 연구. 언어치료연구, 21, 365-388.

안원석(2007). 다문화가정 자녀의 표현 실태분석. 한국교원대학교대학원 석사학위논문.

이금주(2012). 취학전 다문화아동의 문법형태소 산출 연구. 남부대학교대학원 석사학위논문.

정경희, 배소영(2010). 초등 저학년 단순언어장애 아동의 문법형태소 판단능력, 언어청각장애연구, 15, 617-631.

정경희(2014). 1-3학년 학령기 아동의 형태소인식과 읽기능력. 언어청각장애연구, 19, 21-30.

조명한(2003). 언어심리학. 서울: 학지사

행정자치부(2014). 외국인 주민 현황조사. http://www.mogaha.go.kr/frt/bbs/type001/commonSelectBoardArticle.do?bbsId=BBSMSTR_0000000 00014\&nttId $=42492$.

황민아(2003). 언어발달장애 아동의 문법형태소 산출. 음성과학, 10,47-64.

황상심, 정옥란(2008). 경상도 농촌지역 다문화가정 아동들의 언어특성. 언어청각장애연구, 13, 174-192. 